\title{
A Study on the Application of the Cooperative Principle in Business English Letters
}

\author{
Chunxia Zhang \\ Foreign Languages School, Jingchu University of Technology, Jingmen, Hubei, 448000 \\ 568273258@qq.com
}

Keywords: Business English letter; The cooperative principle; Politeness principle; Conversational implicature; Application

\begin{abstract}
With the development of globalization, there is an increasing tendency of business across the world, in which business English letters play an important role in communication. From the perspective of linguistics, the cooperative principle is widely applied in business letters. This essay not only analyzes the application of cooperative principles in business English letters, but also gives detailed introduction about business English letters, which makes readers have a good understanding about business English letters and improve writing skills in relevant fields.
\end{abstract}

\section{Introduction}

There are two kinds of models in business communication: oral communication and writing communication. Generally speaking, oral communication is a formal communication, including meetings, interviews and presentations etc. But there are some drawbacks in oral communication that is business representatives must interact face to face. As we all know, sometimes two parties may have difficulties in communicating face to face because of the schedules and location of companies. In order to exchange information quickly and efficiently, business letter becomes an indispensable part in business communication. Moreover, most business people take the English as their first language to communicate, thus business English letter becomes the most common in business trades.

\section{The Cooperative Principle}

In 1967, H.P Grice, an American Philosopher of language, set up conversational implicature in famous William James Lecture at Harvard [1]. Conversational implicature is regarded as one of the most important theories in Pragmatics and the Cooperative Principle is the score of conversational implicature.

The Cooperative Principle consists of four categories, they are quantity, quality, relation and manner.

Quantity.

1.Make your contribution as informative as is required(for the current purposes of the exchange).

2.Do not make your contribution more informative than is required.

Quality.

Try to make your contribution one that is true.

1.Do not say what you believe to be false.

2.Do not say that for which you lack adequate evidence.

Relation.

Be relevant.

Manner

Be perspicuous.

1.Avoid obscurity of expression.

2.Avoid ambiguity.

3.Be brief(avoid prolixity).

4.Be orderly. 
In short, in the process of communication, both parties should understand the intention of each one, that is the core of the Cooperative Principle. There are considerable studies of the cooperative principle in the world (Brown, Ervin, Rundquist and Michell )[2,3,4,5].

The Abidance and Violation of the Cooperative Principle. Grice set up the Cooperative Principle, at the same time, he pointed out that people would not obey the principles accurately in reality. Sometimes a party would disobey the principle while the other would not. One party disobeys the principle because of some deep reasons rather than telling lies.

The Cooperative Principle and Conversational Implicature. In 1983 British linguists SuephenC. Levinson[6] and Geoffrey N.Leech[7] respectively turned out 'PRAGMATICS' and 'PRINCIPLE of PRAGMATICS', in which both praise Grice's theory of conversational implicature as a most important part in pragmatics.

Conversational implicature surpasses the syntax and semantics to explore the meaning of sentences at first, and it explains the relationship between literal meaning and practical implication of utterance. It consists of two parts:generalized conversational implicature and particularized conversational implicature. Generalized conversational implicature means that when tellers obey some of the principles, their utterances often convey some information literally. On the contrary, particularized conversational implicature means that one party in interaction disobey the principle on purpose to let the other party explore the meaning of communication.

There are five features in conversational implicature: cancellability, non-detachability, calculability, non-conbentionality and indeterninacy.

Cancelability.

Cancelability is the most important of five features. It means adding some words in a certain linguistic context or non-kinguistic context, the meaning of context changes. In a word, it means conversational implicature can be canceled by adding some words.

Non-detachability.

As we all know, conversational implicature is explored through the Cooperative Principle and context, so it is not only relevant to utterance form, but also relevant to contexts. Non-detachability refers to conversational implicature depends on the whole context rather than utterance form. That means, if a certain word or sentence changes, the implicature of the discourse would not change.

Calculability.

Calculability refers to the hearer explores conversational implicature according to the literal meanings of utterance and the Cooperative Principle.

Non-conbentionalit.

Non-conbentionality means that implicature of conversation belongs to particularized implicature rather than generalized implicature. This is because conversational implicatures is achieved by connecting rules of The Cooperative Principle and context. And the implicature follows the meaning of utterance. The conversational implicature will change while literal meaning will not change.

Indeterninacy.

Indeterninacy means that a word or a sentence with single meaning will elaborate different implicature in different contexts.

\section{The Politeness Principle}

Introduction of Politeness Principle. Apart from the rules of $\mathrm{CP}$, politeness is considered to be "another level" to "conversational interaction"[8] and rules of politeness are part of pragmatic competence. People may disobey the cooperative principle for some reasons, and politeness principle, to some extent, can explain why people do not obey the cooperative principle. Politeness principle were concluded by Leech[9], which consists rules as follows:

Tact Maxim

1.Minimize cost to others

2.Maximize benefit to others

Generosity Maxim 
1.Minimize benefit to self

2.Maximize cost to self

Approbation Maxim

1.Minimize dispraise of others

2.Maximize praise of others

Modesty Maxim

1.Minimize praise of self

2.Maximize dispraise of self

Agreement Maxim

1.Minimize disagreement between self and others.

2.Maximize agreement between self and others.

\section{Relationship between Cooperative Principle and Politeness Principle}

Politeness principle is another important part of conversational implicature. Cooperative principle and politeness principle explain how people express their ideas in language using or establish and maintain relationship with others. Politeness principle explains something that cooperative principle cannot solve. In other words, politeness makes up drawbacks of cooperative principle. They all make great contribution to realize communicative intentions.

\section{Relevance Theory}

Relevance theory is set up by Sperber and Wilson,[10] the two linguists make full research on the cooperative principle and they think that relevance theory is simplification of cooperative principle. Relevance theory consists of two parts: cognitive principle and communicative principle. Cognitive principle refers to that human cognition tends to be geared to the maximization of relevance and it represents the basic assumption about cognition. Communicative principle means that every act of communication communicates a presumption of its own optimal relevance. Relevance theory regards the use of language as a psychological matter and it is governed by cognitive principle only.

\section{Case Study of the Application and Violation of Principles in Business English Letters}

Generally speaking, a business letter is used to get or convey information in different departments or companies. It is a very important tool in business trades. As indicated above, many agents tend to use English to express ideas, business English letters are used widely in the world. The aim of business English letter is to convey information correctly and clearly, there are two important parts needing more attention: format and certain rules in business letters. Format consists of formal and informal. Some of business letters such as memo and note can be regarded as informal, however, most of them are formal,which means writers must concentrate on tones of letters. Some certain rules in business letters will lead to good understandings of two parties and help to judge whether the letters are qualified.

\section{Case 1}

Dears Sirs,

Though the courtesy of your embassy in China, we learned that your firm is interested in establishing business relations with a Chinese firm to sell various light industrial products of your country to China.

We have been engaged in import business for many years and are well connected with all the major dealers here. We, therefore, feel sure that we can sell large quantities of your goods if your offers are favorable.

We would like you to send us a catalogue and pricelist, and possibly some samples of the goods that you are principally interested in selling, so that we can study the sales possibility in our market.

As to our credit standing, please refer to Bank of China, Beijing.

We look forward to hearing from you.

Yours faithfully 
( Zhang Cuibo, 2013) [11]

This letter aims to build business relationships with a Chinese firm which specialized in selling lights. In this letter, the Chinese company introduces its specialization in this field and at the same time the company required some samples to show the intention of doing business with the company in foreign country.

From the perspective of cooperative principle, the letter obeys the maxims. in the first paragraph, the writer clearly expresses why he writes the letter and where he gets the information about the foreign company. In the second paragraph,the writer introduces about his company and capability of doing business. In the third and fourth paragraphs, the writer asks price and samples and gives mode of payment, which express the idea that if the price and samples satisfies them, they could give at least a trial order and dong business with the foreign company. In the last paragraph, the writer shows willing of making an order with the foreign company. This letter contains all the information that building business relationship needs. And all the information given is related to building business, at the same time, the writer expresses ideas clearly and logically. So the writer observes quantity, quality, relation and manner maxims in this letter.

In the aspect of politeness principle, the writer conveys the information"well connected with all the major dealers"which means the seller can broaden markets and benefits more, which fits tact maxim. The expressions and sentences used in this letter such as"please refer to Bank of China, Beijing"and "We look forward to hearing from you" are very polite and fits sympathy maxim.

And for the skills and traits of business English letter, the writer avoids ambiguity and uses clear, correct and concise words to express the willing of building business relationships on the foot of sellers.

\section{Case 2}

\section{Ladies/Gentlemen}

From Business Daily of September $6^{\text {th }}$ we have learned about your Business Assistant software package for HP-compatible PCs. As there is a strong demand for it in our area, we would like to find out more information about the package so that we can decide whether it is appropriate to the needs of our customs. If so, we would be very much pleased to do business with you.

Would you mind answering the following questions?

1. Is the program an integrated package, or does it come in several modules?

2. Can the user switch from function to function without down-loading?

3 . Is there any provision for security?

4. Could you give us your best quotation FOB Shanghai?

We would appreciate it very much if you could send us a brochure that describes the package.

Yours faithfully.

(Zhang Cuibo, 2013)[11]

This letter belongs to category of the inquiry letter. In the aspect of writing skills of business English letter, the writer clearly and correctly expresses his willing of dong business and asking relevant things about commodities such as installments, prices, and terms of payment.

As for the application of cooperative principle, this letter observes the maxims of cooperative principle. The letter contains all the information that as a buyer needs. The quantities of information is adequate and appropriate. At the same time the information given in this letter is relevant to inquiry. And the writer uses "would you mind" and "we would appreciate it very much", which fits the manner maxim of cooperative principle.

From the perspective of politeness principle, this letter disobeys some rules. The tact maxim requires that maximize benefit to others. However, the writer requires the seller to give best quotation FOB Shanghai, which violates the tact and generosity maxims of politeness principle. The letter uses "would you mind"and "we would appreciate very much if you could" to minimize disagreement. So the writer observes agreement maxim.

Case 3

Dear Sirs,

We thank you for your inquiry of August 22 and are pleased to send you our quotation for the 
goods you required as follows:

Commodity :White Rabbit Brand Woolen Mixed Blanket No.33

Size: $74 \times 84$ in

Weight: 4lbs

Color:yellow, brown, green

Quantity:1,000pcs

Price:US\$40.00 per pierce CIF Montreal

You are cordially invited to take advantages of this attractive quotation. We are anticipating a large order from the United States, and that will cause a sharp rise in price.

We look forward to receiving your order.

(Zhang Cuibo, 2013)[11]

This letter is a typical quotation letter. This letter correctly quotes the price and specification to the buyer. In the first part, the writer gives the reason why he quotes to the buyer. In the second part, the writer gives full expressions about quotation of commodity. There is no doubt that the writer observes quality and quantity maxims. All the letter is related to the quotation, so this letter fits the relation maxim. The writer express his willing of doing business politely and observes the manner maxim.

In all, this letter observes the politeness principle. The writer says "you are cordially invited to take advantages of this attractive quotation" to give great benefits to the custom. And the expressions like "we thank you for" and "we look forward to "to show modesty of the seller and give a good impression to the buyer, which avoid disagreement.

Case 4

Thank you for your quick and king reply.

Please note we need this shipment on Oct.11

Regarding the 26MT in one HQ/RF Container, we have already shipped during the last 40 days more than 12 Containers with $26 \mathrm{MT}$ in each container.

Please inform us if this date is ok with you? We need it absolutely at this date.

Please inform us if all our design Label Printing is OK.

Awaiting your prompt.

( Zhang Cuibo, 2013)[11]

This mail aims to confirm a shipment. It is clear that the length of mail is shorter than business letter and its expressions is more concise. All the information given is adequate and all of them is relevant to the shipment. However, some expressions in the email may cause some ambiguities. In the sentence of "regarding the 26MT in one HQ/RF Container", the word "MT"and "HQ/RF" may lead to misunderstanding, especially to some green hands in business world. To some extent, the usage of these expressions violate quality maxim. As for politeness principle, although the writer observes it, some expressions such as "please inform us if this date is ok with you" is not as polite as them in business letters.

\section{Conclusion}

With the increasing development of business, business English letters play an important role in different kinds of business activities. Business letters need to convey information efficiently. As a writer, he or she should use clear and concise words to express ideas naturally with attitudes of sincere and friendly.

As most business people would like to communicate through business letter,the cooperative principle is also applied to business English letter. And of course, sometimes writers have to break cooperative principles for some reasons and the politeness principle is a significant one.

In a conclusion, an excellent business English letter not only requires a good English foundation, but also master good skills as well as principles of pragmatics. Writing a good business English letter may lead to a successful trade. 


\section{Acknowledgements}

This work is financially supported by Hubei Education Science "12th Five-Year Planning" (Project No.2014 A039) and Teaching Research Project of Jingchu University of Technology (No.JX-201634).

\section{References}

[1] H.P. Grice: Logic and Conversation (New York: Academic Press, America 1975).Vol. 43 (1994) No.3, p.305.

[2] P. Brown: Discourse Processes, (1990) 13:123- 141.

[3] E. Ervin: The Rhetoric of Courtship: Conversation and Cooperation in Newspaper Personal Ads. (1990) ERIC, ED 318072.

[4] S.Rundquist: Journal of Pragmatics, (1992) No. 18, P. 431- 449.

[5] G.Michell: Women and Lying: A Pragmatic and Semantic Analysis of "Telling It Slant". Women's Studies International Forum, (1984) No.7 p.375- 383.

[6] S. C. Levinson: Pragmatic (Foreign Language Teaching and Research Press, China 1983).

[7] Leech G: Principles and Pragmatics (London: Longmans, Britain1983).

[8] Fasold R: The Sociolinguistics of Language (Foreign Language Teaching and Research Press, China 2000).

[9] Z. X. He: An Introduction of Cognitive Pragmatics (Shanghai Foreign Language Education Press, China 2000).

[10]D. Sperber and D. Wilson: Relevance: Communication and Cognition (Oxford University Press, Britain 1986)

[11]C. B. Zhang: Practical: English Writing for international Business Writing (Qinghua University Press, China 2013. 